УДК 681.5

S.V. Pokhnatiuk, O.M. Sovhar, Y.V. Ryzhov

Army Academy named after hetman Petro Sahaydachnyi

\title{
MULTIPLE INTEGRATED LASER ENGAGEMENT SYSTEM ITS EMPLOYMENT IN THE ARMED FORCES OF UKRAINE
}

The article provides an insight into the multiple integrated laser engagement system (MILES), history of its evolution, concept of training, states rationale for using it in the combat training of the Ukrainian Armed Forces.

Key words: multiple integrated laser engagement system (MILES), simulation, weapons systems.

\section{Introduction}

\section{Problem statement}

The Multiple Integrated Laser Engagement System (MILES) is a training system that provides a realistic battlefield environment for soldiers involved in training exercises. MILES provides tactical engagement simulation for direct fire force-on-force training using eye safe laser "bullets". Each individual and vehicle in the training exercise has a detection system to sense hits and perform casualty assessment. Laser transmitters are attached to each individual and vehicle weapon system and accurately replicate actual ranges and lethality of the specific weapon systems. MILES training has been proven to dramatically increase the combat readiness and fighting effectiveness of military forces. The system creates a realistic tactical engagement simulation environment for soldiers and security forces training in the field against an opposing force. MILES adds realism to training by reinforcing the requirement for individuals and units to adhere to operational doctrine.

\section{Objective formulation}

The article is aimed at examining the Multiple Integrated Laser Engagement System, history of its evolution, concept of training, suggesting rationale for using it in the combat training of the Ukrainian Armed Forces.

\section{Main part}

General overview Soldiers use MILES devices primarily during force-on-force exercises, from squad through brigade level, to simulate the firing and effects of actual weapons systems. These weapons systems include the M1 Abrams Tank, Bradley Infantry Fighting Vehicle, M113 Armored Personnel Carrier, wheeled vehicles and other non-shooting targets. Additionally, MILES simulations address anti-armor weapons, machine guns, rifles, and other ancillary items, such as a controller gun, within the program [1].
MILES requires the sound of a blank cartridge to discharge a laser transmitter that sends simulated laser "bullet" to kill or wound opposing forces (OPFOR) during training exercises. The MILES fires coded laser beams at laser detectors attached to soldiers or vehicles. When the laser beam hits a detector, the laser detector records a kill or near miss. The detectors are sensitive to the source of fire. For example, the laser beam for a soldier simulating the firing an M16 rifle will not register on a detector mounted on an armored vehicle. Blank firing attachments were developed to promote realism by enabling soldiers to simulate firing their weapons as they are actually used on the battlefield.

Both combat vehicles, such as the M1 Abrams tank, and various support vehicles can be instrumented using vehicle-specific Vehicle Detection Device (VDD) kits. Vehicle kits are comprised of a VDD console that mounts inside the vehicle and provide the functions of MILES decoding, SAWE (Simulated Area Weapons Effects) indirect fire and mine effects events decoding and damage assessment. The console includes the GPS receiver for position location determination. Position location, and direct and indirect fire event reporting is accomplished through the associated DCI which is also mounted within the vehicle [1]. A system of MILES detector belts designed to fit specific vehicles are mounted on the exterior of the vehicle using velcro. The GPS and DCI antennas are also mounted on the exterior of the vehicle.

Different versions of MILES systems are available both within the US and internationally. Amongst the most widely used are MILES Individual Weapon System (IWS), Wireless Manworn MILES, Wireless Vehicle MILES, Precision Gunnery System, Military Operations on Urban Terrain (MOUT) Building Instrumentation. The capabilities of the individual systems can vary significantly but in general all modern systems carry information about the shooter, weapon and ammunition in the laser [1].

Milestones of MILES evolution The US Army developed the original family of MILES devices ("Basic 
MILES") in the late '70s and early '80s using state-ofthe-art technology of that time. Basic MILES was the primary training device for force-on-force training at Army home stations. However, training battlefield required an improved performance level Basic MILES could not meet. Existing Basic MILES technology did not support the level of fidelity Army commanders and trainers require. Basic MILES failed to record any event data for use in After Action Reviews. This was a major handicap in providing soldiers feedback. Basic MILES systems have reached the end of their useful economic life cycle. Due to these shortcomings, the Army made the decision to buy devices reflecting improved weapon fidelity and reduced logistics burden [2]. Examples of logistics support advances found in the latest generation of MILES include longer life batteries, reduced power consumption by components, advanced electronics design, and more rugged and robust equipment with reduced operation support costs.

In 1993, the US Army initiated the MILES 2000 program with Operational Requirements Documents entitled MILES 2000. The purpose of this program was to replace the basic MILES training systems. MILES 2 was released in 1991 - 92, and the SAWE (Simulated Area Weapons Effects) add-on was first fielded in 1992 using GPS and RF messages so that vehicles and individual soldiers can be killed from a central location due to artillery strikes, or Nuclear, Biological, and Chemical weapons strikes. Implementation in the Summer and Fall of 1992 was at Hohenfels, Germany at the Combat Maneuver Training Center. The Army fielded MILES 2000 training equipment at all USA home stations. The MILES 2000 program included Basic MILES functionality, compatibility with the direct fire component of Simulated Area Weapons Effects-Radio Frequency/MILES II (SAWE-RF/MILES II), usability improvements, and training effectiveness increases made possible through commercial off-theshelf integrated circuit and laser technologies [1].

MILES 2000 used laser light in the form of pulses to transmit weapon information to a target. These pulses are transmitted each time a weapon is fired. Information contained in the pulses includes the player ID and the type of weapon used. The target entity processes the information to produce a casualty assessment. The casually assessment for a dismounted soldier can produce a state of killed or wounded. The casualty assessment for a mobile weapon system can produce several outcomes, which include catastrophic kill, mobility kill, and communication kill. Both dismounted soldiers and mobile weapon system platforms are equipped with a laser transmitter and laser receiver. The ability to support an After Action Review is an essential feature of the MILES 2000 training system. This is possible because all player activity is recorded during an exercise. MILES XXI is the follow-on production procurement of MILES 2000.

Cubic Defense Applications has adapted laserbased tactical engagement simulation systems for soldiers, vehicles, direct fire weapons, indirect fire weapons, area weapons effects, buildings.

Wireless Multiple Integrated Laser Engagment System for Vehicles ensures better training fidelity, wifi communications and intuitive interfaces. Cubic's wireless vehicle Multiple Integrated Laser Engagment System is an advancement in wireless solutions for simulation training. From the modular system architecture down to and including the training devices, the system is configured with new features that significantly improve ease of use for soldiers engaged in force-on-force and force-on-target training [3]. The system includes significant advancements in the user interface. Touch screens display highly intuitive graphics for tech savvy soldiers. This commercial-off-the-shelf technology makes system setup, installation, and operation significantly easier than other tactical laser engagement simulations systems in use today [5].

Amongst its benefits are:

Intuitive - provides high value content user interfaces coupled with smart phone technology to simplify installation and operation of the system.

Multiple Growth Paths - modular design supports growth through upgrades, software/configuration changes, and technology insertion.

Reduced Cost of Ownership - no cables mean less spares, repairs, maintenance, and logistics over the life of the system.

Precision - replicates the effective range and ballistics of all potential ammunition, and provides real time casualty assessments for after action review and learning.

Modular Configuration - adapts to any wheeled or tracked tactical vehicle and is also configurable for buildings, fixed equipment, and other structures.

MILES Individual Weapon System (IWS) is the U.S. Army's latest generation tactical engagement simulation system in use today. The armies of the USA, Australia, the UK, Croatia, Chech republic, Finland, Germany, Austria, Hungary, Georgia, Ukraine and many other countries chose MILES IWS to replace basic MILES at their home stations and Combat Maneuver Training Centers.

Compatible - designed to interface with homestations, CTCs, Military Operations in Urban Terrain (MOUT) facilities.

Easy Alignment - Requires only seconds to align a weapon.

Less Equipment -Visible laser alignment in any light - day or night - without an automated alignment device. 
Lighter Payload - Entire kit weighs $<1,58 \mathrm{~kg}$ including batteries [5].

With this equipment, soldiers make better use of training time by spending less on setup and calibration, and more on tactics. MILES IWS requires less time to attach a SAT and align a weapon than previous versions, and maintains alignment during an entire exercise. As a result, soldiers have increased confidence in the tactics they practice during training.

Integration of MILES into Ukrainian Armed Forces combat training system. MILES fielding into Ukraine started in 2008 in Zhytomyr's Korbutivka Military Installation and Ukrainian Training Area. The first sets of MILES equipment were turned over from the US Government to the 95th Airmobile Brigade, and subsequently to training Area 40.

New Equipment Training (NET) was completed to qualify all required personnel on the components of MILES, i.e., the Small Arms Transmitters (SATs), Haloes and Harnesses, Control Guns, and the MILES After- Action Review software (MARS).

A major "proof of concept" exercise/demonstration was conducted for Senior UAF and US leaders to include Commander Land Forces Command and the US Ambassador.

The following Concept of training was adopted to integrate MILES into Ukrainian Armed Forces combat training system:

Fielding is intended to support the integrated, multi-echelon training of a rifle company. A general description of training for each echelon is listed below.

Phase I, Individual Skills - 3 Days

a. Riflemen: Combat Marksmanship - effective engagement of targets while under stress and under fire. This event is a combat biathlon that combines running, shooting, and tactical movement. Its purpose is to develop within each rifleman the ability to acquire and engage targets when fatigued, under stress, and under fire. It is progressive in that each exercise is more challenging than the last. It is demanding in that, between iterations, the soldiers must run 300 meters. Common tasks integrated into the various iterations include reloading, immediate action to clear stoppages, and re-association with different weapons. The iterations include, inter alia, the following:

1. Engagement of stationary targets at combat ranges from a tactical position.

2. Engagement of other patterns of targets, requiring the rifleman to choose which targets to engage first and in subsequent order, and put deliberate, aimed fire on the targets identified.

3. Engagement of targets while experiencing 'near misses', requiring repositioning.

4. Assault fire, moving from covered position to covered position, under fire coming from the 'targets'. b. Machine Gunners: Fire support - The establishment of a base of fire in support of the maneuver of the rifle squads, including machine gun emplacement, fire control, and the use of signals to commence, lift and shift fires, and displace. This event will consist of a circuit of two kilometers. At various stations along the circuit the machine gunners will deploy into designated positions with the fields of fire concealed from them. The machine gunners will have to engage the target arrays using proper technique, and hit all targets. After the engagement of the targets, the machine gunners will react to signals to shift fires and displace at a sprint to a forward position, and then resume the circuit. The target arrays the machine gunners will engage include, inter alia, the following:

1. Flanking fire, troops on line ('traverse' targets)

2. Enfilade fire, troops in column ('search' targets)

3. Frontal fire, troops in echelon ('traverse and search' targets)

4. Displacement from primary to alternate or supplementary positions, followed by target engagement.

5. At various stations along the circuit, the machine gunners will have to clear stoppages, react to 'near misses', react to enemy fire, and associate their weapons.

c. Snipers: Tactical Target Engagement - The detection and selection of appropriate targets, engagement techniques, camouflage, and displacement. Similar to the machine gunners, the snipers will traverse a circuit, with stations along the way where they will have to detect and engage suitable sniper targets. Points of performance include, inter alia:

1. A rapid, detailed survey of the battlefield

2. Assessment of target priorities in terms of the degradation of enemy capabilities, risk of counter-fire, probability of kill

3. Selection, preparation, and camouflage of firing position

4. Displacement to subsequent positions

5. Response to hand and arm signals

Phase II, Marksmanship at Section Level - 3 Days

1. Movement techniques, formations, and battle drills - During this phase the section will practice proper movement techniques in accordance with the tactical situation considering the factors of METT-T and the proper actions upon encountering the enemy. Actions to be practiced include:

1. Movement formations, such as line, file, column, wedge, wee.

2. React to contact, react to ambush.

3. Actions upon encountering the enemy - Drills oriented on response to the most critical combat situations.

4.Target engagement - During this phase, the section will integrate all the individual firing techniques 
practiced earlier to use effective massed fires against an armed enemy in order to gain fire superiority and create the conditions necessary for a successful assault. Specific actions to be practiced include:

1. Fire distribution, so that effective fires are placed on all points within an enemy array of targets.

2. Fire and movement techniques, to close with the enemy while avoiding friendly casualties, especially fratricide.

c. Phase III, Platoon Tactics - 5 Days

Fire and maneuver - This is the basic platoon tactic supporting almost any mission. The basic elements include the selection of a position and deployment of appropriate weapons to establish a base of fire and then the development of a scheme of maneuver to close with the enemy. Key techniques include the coordination of the two elements so that enemy fires and maneuver are suppressed and fratricide is prevented. Fire and maneuver supports the following mission essential tasks:

1. Deliberate Attack - An attack conducted according to a detailed plan, usually coordinated with the attack of units on the flanks and the application of indirect fire support.

2. Movement to Contact - The tactical maneuver of the platoon when contact with the enemy is expected but the specific time and locations are unknown. In this task, the platoon leader must maneuver his platoon in a formation that will facilitate the most expeditious reaction to enemy contact, which usually entails some sort of fire and maneuver.

3. Hasty Attack - The maneuver of the platoon when it makes contact with the enemy and, for whatever reason, it is disadvantageous to do the detailed planning required for a deliberate attack. Usually a hasty attack is the culmination of a movement to contact, and requires the selection of a position for a base of fire and the rapid selection of a scheme of maneuver.

4. Defense of a Battle Position - While the defense of a battle position is chiefly characterized by the deliberate, detailed selection of firing positions for all the platoon's weapons, the defensive plan should make provision for maneuver for the displacement to alternate or supplementary positions and counterattack. Under these circumstances the base of fire should prevent the fire and maneuver of the enemy and support the elements of the platoon that make the actual maneuver.

5. Withdrawal - A withdrawal can be thought of as fire and maneuver 'to the rear'. A detachment left in contact will lay down covering fire sufficient to cover the withdrawing elements and mask the conduct of the withdrawal. The maneuvering element will displace to the next covered and concealed position to the rear, and then serve as the base of fire for the withdrawal of the detachment left in contact.
6. Ambush - An ambush is an offensive operation in which the base of fire plays the central role, that is, the destruction of all targets in the 'kill zone'. The base of fire should then support the ensuing actions, such as clearing the kill zone and the search for documents, key weapons, and the capture of prisoners. The base of fire should then cover the withdrawal of the platoon from the ambush area.

5. Reconnaissance Patrol - While the object of a reconnaissance patrol is to avoid contact with the enemy in order to gain intelligence, if contact is made a base of fire should provide enough immediate shock action in order to permit the patrol to break contact and resume its mission.

6. Raid - A raid is an offensive operation during which an objective is achieved without the capture and retention of terrain. The organization of the platoon for a raid includes an assault element, that actually performs the assigned mission, and a fire support element, that gains fire superiority and covers the assault element.

Phase IV, Company Tactics - 4 Days

1. Troop Leading Procedures - The emphasis at company level will be on the actions and procedures required to plan and execute the company's mission essential tasks. In contrast to platoon- and section-level operations, at company level there are more formal troop leading procedures that concentrate on the integration of the company's organic assets and the weapons placed in support, such as mortars and artillery. The company commander is responsible for the achievement of the synergy resulting from effective combined arms planning.

Orders - The outcome of the troop leading process is a combat order that:

1. Defines responsibilities and command relationships.

2. Succinctly describes the enemy, friendly, and environmental situations.

3. States the mission in unambiguous terms.

4. Describes the scheme of maneuver and plan for fire support.

5. Assigns missions to each subordinate and supporting unit.

6. Describes the concept necessary to sustain the operation.

7. Describes communication and command procedures [6].

MILES was introduced into the Army Academy in 2010. FTX, during which cadets of mechanized, airborne, and reconnaissance units used this equipment proved its effectiveness in both individual and collective training. When asked about the benefits of its application instructors stated that it added a great deal of realism into the training. Having replayed each operation using MARS, instructor was able to acquire information about 
each soldier's location, movement, and fire engagement, which would aid him in evaluation of each cadet's performance.

Some shortcomings of the system are also worth mentioning. First of all, all the component parts are produced abroad and there are no domestic equivalents. Simulation of firing is done using only blank cartridges, which leads to increased ammunition expenditure. Technical issues can be solved only by representatives of the Cubic - company manufacturer. In addition, system allows a sort of "cheating" - when dishonest soldier covers the detector, becoming "immortal".

However, on the whole, the shortcomings do not diminish the overall efficiency of the system. That is why it is planned to continue MILES employment in the Army Academy. Moreover, research and development work on development of domestic equivalents of laser engagement systems is to be initiated.

\section{Conclusions}

MILES has revolutionized military training methods and techniques. Using MILES, the individual soldier receives immediate feedback as to the effects of his actions on the battlefield. By "killing" his opponent if he performs correctly and being "killed" if he errs, actions which will permit the individual soldier to perform effectively in the modern battlefield are reinforced. Employment of MILES training system has proven to be quite instrumental in efforts to increase effectiveness of the the Ukarinian Army combat training system.

\section{Literature}

1. [electronic resource] www.fas.org/man/dod-101/sys/.../miles.htm

2. Operator's manual for Multiple Integrated Laser Engagement System (MILES), simulator system, firing laser, M83, 2002. - $102 p$

3. Training device operational requirements document for replacement of ground direct fire tactical engagement simulation (tes) devices cards number 0291 revision jul 96

4. http://www.cubic.com/Defense-Applications/

Training-Systems/Multiple-Integrated-Laser-EngagementSystem/Customized-Solutions

5. [electronic resource] http://www.prc68.com/I/MILES.shtml

6. [electronic resource] http://www.lockheedmartin.comproducts/MultipleIntegratedLaserEngagement/index.html CV_TES

7.[electronic resource] www.peostri.army.mil/...IMILES -

Reviewer: doctor of technical sciences, professor V.M. Koroliov, Hetman Petro Sahaydachnyi Army Academy, Lviv.

\title{
БАГАТОЦЛЬОВА КОМПЛЕКСНА ЛАЗЕРНА СИСТЕМА УРАЖЕННЯ ЦІЛЕЙ (МІLЕS) ЗАСТОСУВАННЯ У ЗБРОЙНИХ СИЛАХ УКРАЇНИ
}

\author{
С.В. Похнатюк, О.М. Совгар, С.В.Рижов
}

У статті надано аналіз Багатоиільової Комплексної Лазерної Системи Ураження Цілей (МILЕS), висвітлено досвід застосування у ЗС Украӥни та окреслено стан і перспективи впровадження MILES у систему підготовки курсантів Академії сухопутних військ.

Ключові слова: багатоиільвова комплексна лазерна система ураження иџілей (MILES), імітаційне моделювання, системи озброєння.

\section{МНОГОЦЕЛЕВАЯ КОМПЛЕКСНАЯ ЛАЗЕРНАЯ СИСТЕМА ПОРАЖЕНИЕ ЦЕЛЕЙ (МІLЕS) ПРИМЕНЕНИЕ В ВООРУЖЕННЫХ СИЛАХ УКРАИНЫ}

\section{С. В. Похнатюк, О.М. Совгар, Е.В.Рыжов}

В статье приведен анализ Многоиелевой Комплексной Лазерной Системы Поражения Целей (MILES), освещен опыт ее применения в ВC Украины, а также использования MILES в системе подготовки курсантов Академии сухопутных войск.

Ключевые слова: многочелевая комплексная лазерная система поражения целей (MILES), имитационное моделирование, системы вооружения. 